\title{
Philosophical Teaching and Cultivation of Students' Creative Thinking
}

\author{
Yang Xiaoning \\ Dalian University, China
}

\begin{abstract}
Philosophy has unique features different from other disciplines. It through the most abstract language categories summarily expresses and presents human's creative ability and enterprising spirit different from animal. Philosophy is critical in nature. This criticalness embodied in philosophy should constantly awaken, develop and promote self-consciousness of human. Understanding the nature and function of philosophy is to follow the nature of philosophy, promote teaching reform. By class and extracurricular forms and means trains and cultivates variously students' creative thinking ability.
\end{abstract}

Keywords: Philosophical essence; Philosophical teaching; creative thinking

Philosophy is a very special discipline, whose nature seems difficult to grasp. However, from the development process of philosophy history, it can be found that philosophy in every age pays attention to humans' existence state and the problems of it and is committed to the exploration for more reasonable mode of human existence and development, so as to get rid of the crisis, walk out of predicament. This should be the particular function of philosophy that different from other subjects. Philosophy generally expresses and presents human spirits which constantly improve, pursue, and create, different from animals', by the most abstract linguistic categories.

\section{Philosophical Transcendence and Human Creativity}

From the philosophical point of view, the most fundamental difference between humans and animals is that humans can create their own life and realize selfdevelopment. The Marxism holds that the human nature is basically human practice. And human practice means that humans are creative historical existence. People continually create their own future while they constantly go beyond and deny the reality. It is this practice that constitutes the most direct and realistic base and source of human creativity. Only through labor can people maintain and develop their life. Only through the change made to objective world can people approve themselves. All things around humans are created by themselves. They use their own hands for laying the road to the future, creating the home for living. At the same time, humans who are both the result of natural evolution and the interruption of natural evolution which is prominently revealed in the fact that humans have evolved from animals with simple adaptability into a species with subjectivity, initiative and creativity, realize the creation of their own. Since nature just finished creating a half of a human before it brought humans to the world, they had to rely on themselves to complete the other half. So it can be said that humans are unfortunate "lucky ones" in the universe. 
We know that human is not perfect as a species in biological sense, because human organs are not specialized yet, and human instinct cannot withstand a single blow. Without all kinds of inherent advantages, humans not only continue their lives in accordance with the natural life "program" but also create their unique life pattern following the "ideal set" of valuable life, instead of confining themselves to the imperfect biological characteristic. This is the unique human nature of transcendence and creativity, which is the fundamental distinction between humans and animals. Marx pointed out when he tried to make a distinction between animals' life and human life that: "Animals only create according to the yardstick and needs of the species it belongs to, while humans know how to create following any standard, and can measure objects by inherent yardstick in anytime, anywhere. Therefore, humans create in accordance with aesthetic law". [1]

The "creative" means of human being is the deep human nature basis of exploring people's creative thinking. Philosophy's nature and abilities of selfcriticism, self-renewal and selftranscendence are the generalizations of thought about people's nature of creating. Philosophical transcendence is pregnant with the desire and impulse to break the finite natural space-time and to create future, featuring human creativity. Philosophy reflects human inherent characteristic of self-conducting most profoundly by using its peculiar language through rethinking about human survival status. So only through philosophical transcendence can we understand the true meaning of human and life creativity. Philosophy always criticizes and rethinks of humans' understandings of the world and transformations to the world by spirit of transcendence; it always guides people to raise "ought to be" on the basis of "be".
People grow up during this process where they constantly surpass themselves, create and assume higher being of subject. Also in this process, philosophy has become the indispensable internal factor of human life with creative nature. Philosophical critique and rethinking give humans eternal encouragement and guidance, give the subject, humans, the infinite creativity.

\section{Philosophical Teaching and Stu- dents' Creative Thinking}

Philosophy, as a kind of innovative wisdom, opposes that people take readymade approach to the popular attitude to life, way of thinking, values, aesthetic taste and objects to people lying in the unchallenged hotbed following the beaten track. It stimulates rather than restrains human imagination, creativity and criticism; it shocks rather than strengthens the inertia, conservativeness and coagulation in human thoughts; it promotes rather than contain humans' subject consciousness, rethinking attitude and creative spirit. Because of all above, philosophy can improve people's thinking ability, cultivate and strengthen people's awareness to create, improve the comprehensive quality. The scientific knowledge of philosophy's characteristic, nature and function is the theoretical foundation of philosophical teaching reform.

The radical difference between philosophy and other disciplines is that philosophy is a kind of thinking. This kind of thinking is the thorough knowledge of and beyond the ego thought and emotion, reflecting people's attitude to life and realm of thought. In a certain sense, the quality of a nation, a social class, even a person can be reflected by its own philosophy. However, in the current examoriented education system, schools, teachers, and parents focus a lot on students' academic performance and secular promise, but ignore their basic quality 
education, especially cultivation and excavation of the thinking ability and creative ability. Students are busy at having classes, doing homework, taking exams all day, almost having no time to communicate with others, just thinking about the external material world not internal spiritual world, so the only bit of passion and spirituality students had are forgotten and sealed by exam-oriented education. Therefore, when they face the complicated reality of life, they are either helpless, feeling it hard to make a choice, or become obstinate and irrational tending to make simple choices. As a philosophy teacher, we have the responsibility and obligation to follow the nature of philosophy, to actively promote the teaching reform, to find out a suitable teaching means for improving students' thinking ability and expanding students' thinking space under the current situation.

Understanding the nature and function of philosophy is the premise of following the nature of philosophy and advancing teaching reform. Philosophy means "to love wisdom" and the focus is on the word "love". In the pursuit of "wisdom", knowledge does not equal wisdom. Teachers should embody wisdom as much as possible while teaching theoretical knowledge to affect students positively. Also, they should be good at acquiring materials of wisdom from history and reality and using these materials in the teaching process in order to cultivate students' love for wisdom and guide students to experience what is wisdom. Philosophy pursuing truth, kindness and beauty, is a cultivation of rational spirit, good practical action and purely beautiful mind. Philosophy is also a discipline which pursues metaphysics. So philosophical teaching should be based on metaphysics, but reflect the concrete objects, not only teaching students to think rationally, but also integrate theory with practice. Philosophy is the essence of spirit of the time, which is supposed to be used to change the world as well as explain the world. Philosophical teaching should be closely related with the reality of contemporary world and China, not just limited in books. Philosophy is all about human beings, and the core of philosophical teaching is to give people all-around education which includes teaching theoretical knowledge, abilities, wisdom, standard of value, spiritual realm and so on.

\section{Ways of Cultivating Students' Creative Thinking}

People solve the problems in the world by using wisdom and creativity. With the advent of the age of information, people are not lack of knowledge and information any more, but the ability and wisdom to control and discriminate knowledge and information. The focus of the competition among elites is no longer the amount of knowledge, but the flexibility and creativity of thoughts. Nowadays, how to maximize individual potential intelligence has become the strategic problem to every country. As an educator of higher education, it is necessary to strengthen the awareness of educating thinking abilities, pay attention to the cultivation of students' innovative thinking, and actively explore effective ways of implementing innovative education.

Many scientists have pointed out that a person's thought is most active in youth, when he has the most doubt, the richest imagination and is more likely to ask questions. Therefore, education is to exploit the potential innovative abilities of each student. In this respect, philosophical teaching should concentrate efforts on the following aspects:

First, teachers should ask more questions while teaching to stimulate students' interest. Interest is the motivation of creation, the precursor of success. Every crea- 
tive achievement is obtained from strong interest in the researching field. So teachers should design questions that students are interested in, in order to guide the students to think, research and explore. This requires teachers to prepare for lessons carefully, designing questions elaborately, linking and using literature, art, science, technology, life and so on appropriately, to arouse students' study interest and maintain the active state of mind.

Second, the heuristic education should be implemented to cultivate students' ability of independent thinking. Teaching in university is not a simple imparting of knowledge, but enlightenment. Therefore, teachers should not give students definite answers; they should use more interrogative sentences instead of imperative sentences, consciously cultivating students' ability of thinking. In the meantime, deliberate training of innovative ability is necessary, such as flexible thinking, divergent thinking and reverse thinking, etc. It is teachers' duty to develop their potential creativity, innovative initiative and pass on the strategy to master innovative thinking.

Third, carry out constitutive teaching to cultivate students' consciousness of criticism. Since most young students having antagonistic psychology, don't have blind faith in authority, teachers can cultivate students' ability of innovation and practice through teaching steps such as choosing, appreciating and acting. Teachers should not just transmit knowledge, but give students the initiative of study, letting them critically think about the knowledge accumulated in human history. Just as the old saying goes, there's no creating without breaking. When there is no criticism, there is no innovation. Criticism is the source of innovation.

Fourth, strengthening education of responsibility to promote students' sense of mission is important. People having independent enterprising spirit should have a broad humanistic care, fully demonstrating the individual morality and responsibility to society, country and human beings. Even in the age of market economy, people who truly accepted higher education and nurture of university culture should go beyond the material gains, establishing lofty goals and should know not only "how to live", which means mastering the knowledge and skills to survive, but also "why to live", which means understanding the meaning and value of life and always adhering to the value principle of truth, kindness and beauty. Lev Tolstoy believes that a man without passion would never succeed and the sense of responsibility is where passion comes from. People who have the sense of responsibility can achieve the unity of individual development and social development, hence the strong desire to be elites and the great motivation to innovate.

\section{References:}

[1] Marx. 1844 years of manuscript of economics and philosophy. People Press, 1979: 50-51. 